\title{
Anatomy as Epistemology: The Body of Man and the Body of Medicine in Vesalius and his Ancient Sources (Celsus, Galen) ${ }^{1}$
}

\author{
ROBERTO LO PRESTI
}

Humboldt-Universität, Institut für Klassische Philologie

Dans la préface au De humani corporis fabrica Vésale dénonce l'absence d'unité du savoir médical comme une des raisons principales de sa décadence. Il décrit les processus sociaux ainsi que culturels qui ont mené la chirurgie à se séparer de la diététique, et cette dernière à se séparer de la pharmacologie, en déterminant une sorte de vide dans l'art médical. Son projet anatomique est donc à considérer dans le cadre d'une plus vaste reconsidération des questions concernant la définition de la médecine, son organisation et division disciplinaire. Cet article vise à éclairer cet aspect "épistémologique" et méta-anatomique, pour ainsi dire, du projet anatomique de Vésale, en analysant la structure rhétorique de sa polémique contre la fragmentation de la médecine ainsi que les sources anciennes (Galien et Celse) de cette polémique et la manière dans laquelle Vésale se réfère à ses sources et les adapte à ses objectifs et à son horizon méthodologique et théorique.

\section{Introduction}

$\mathrm{D}$ efining a branch of knowledge as a discipline primarily consists of two steps: 1) saying what that discipline is, what its subject is, what theoretical aims it has, and which methodological strategies it adopts; and 2) establishing its boundaries in exploring and accounting for the fields of human experience. To use the metaphor of the body, we can see that the first step provides the "flesh" (matter) of a discipline, while the second step provides the "skin," or what distinguishes a bodily (and in this case a disciplinary) unity while connecting it to its context. Along with these two basic operations, however, we must include a third defining process: one of partition and specialization of a discipline into more or less autonomous or interconnected and interdependent 
sub-disciplines. In fact, phenomena of disciplinary partition have the power to retroactively influence and orient the whole definitional process of a discipline, as they engender phenomena of hierarchization and compartmentalization of the knowledge acquired, as well as phenomena of differentiation of the methods and of the cognitive strategies adopted. As regards "the flesh" of a discipline, specialization introduces difference into a unitary body, and, so to speak, modifies an undifferentiated whole into an articulate system. This, however, also has important consequences for the "skin" for at least two reasons: 1) specialization, while in principle penalizing those forms of knowledge that develop horizontally and in width, is characteristically productive of "vertical" and in-depth knowledge as well as of technical effectiveness (which leads to an overall enlargement of the cognitive and operational domain of a discipline), and also of disciplinary inhomogeneity, since single branches of the same discipline can develop at a different velocity and in different directions or even implode while others are rising; 2) specialization can cause, and has in fact often caused, a tension between partition and disciplinary unity that is so violent and unsustainable that it eventually engenders the fragmentation of a discipline into two or more distinct and autonomous branches of knowledge.

If it is generally true that processes of disciplinary definition and redefinition have often been intertwined with, influenced or paralleled by processes of partition and specialization, this sounds even truer for medical knowledge, in that it is the very subject of medicine's investigation that embodies the essential tension between unity and differentiation, coherence and articulation. This tension is intrinsic to the anatomical structure of the human body, and is implicit even in the most roughly intuitive representations of the body as composed of a trunk, a head, and four limbs. This is why I have decided to address the issue of the definitions and redefinitions of medicine in the Renaissance by focusing on the views on specialization of Vesalius, the author of the highly celebrated De humani corporis fabrica (1543), ${ }^{2}$ whose contribution to the constitution - or the resurrection - of scientific anatomy and consequently to the birth of "modern" medicine is universally considered fundamental, if not even foundational. ${ }^{3}$ 


\section{Vesalius, the Ancients, and the "resurrection" of anatomy: combining rejection and imitation}

It is not by chance that I have used the term "resurrection," as Vesalius's intellectual enterprise largely depended on the unceasing dialogue he established with the ancient authorities of medicine. Also his views on medical specialization cannot be fully appreciated if not in the light of, and in parallel with, the opinions that his ancient sources expressed on such matters. Scholars have long acknowledged that Vesalius, like his predecessors and contemporaries, never aimed to reject entirely the anatomical knowledge of the Ancients and more specifically the knowledge transmitted by Galen's teaching. ${ }^{4}$ On the contrary, Vesalius's approach to this heritage was positive (R. French has even defined Vesalius as "more Galenic than Galen"5), insofar as he looked at it from an almost entirely unheard of methodological perspective, a perspective which resulted in "a complicated mixture of dependence, reworking and critique" and which, for this reason, was antithetical to most of the two-centuries-long tradition of anatomical writings inaugurated by Mundinus's Anothomia, ${ }^{7}$ which tradition was dogmatically Galenic. Put in these terms, the question is not if Galen was still considered as the model of reference by Vesalius, but which Galen (that is, which aspects of his anatomical teaching and which of his works) Vesalius looked at, with what attitude of mind, and for what purpose. Mondinus's Anothomia, and consequently a large part of the Pre-Vesalian Mondinus-based anatomical investigations, were based on Galen's most important work on functional anatomy, the De usu partium. One exception (as is the case with Mondinus) was the use of the De Juvamentis Membrorum - an excerpted and compressed Latin version of Galen's De usu partium (or rather, a Latin translation of an incomplete and unsatisfactory Arabic version of Galen's original), whose full text was first rendered in Latin only in the early fourteenth century (1317) by Niccolò da Reggio (c. 1280-1350), physician and translator of Greek medical texts at the Angevin court. ${ }^{8}$ Both the aim of the De usu partium - to praise the harmony of the body and the purposefulness of each of its parts - and its structure served as a theoretical and practical model of reference for all the anatomical investigations based on the so-called three-venter dissection. ${ }^{9}$ By contrast, no Latin translation of Galen's main work on morphology and the techniques of dissection, the De anatomicis administrationibus, was available until $1531,{ }^{10}$ when books I-VIII and a part 
of book IX were translated by Guinther of Andernach, who was Vesalius's teacher in Paris. ${ }^{11}$ It was Vesalius who first followed the lesson of De anatomicis administrationibus in his De humani corporis fabrica, giving priority to the exposition of the "common parts" of the body (bones, nerves, muscles, veins and arteries) before dealing with the structure and functions of the organs and the apparatuses. ${ }^{12}$

Insofar as my paper deals with the impact that Vesalius's anatomical project had on the definition of both the external and the internal boundaries of medicine as a disciplinary field, two further points are to be raised. Firstly, as we distinguish between "dissection" and other (for example, ritual) forms of inspection and practices of manipulation of the inside of the body, ${ }^{13}$ we should also draw a distinction between "dissection" as a technical procedure that allows one to penetrate and inspect the inside of the body by cutting, separating, and removing different strata of matter, and "anatomy" as a "practice of thought" and, so to speak, as "narrative," by which I mean a normative way of describing and representing the dissected body as a stratified unity composed of interdependent structures and interconnected parts. In a very general way, one could say that while dissection as a technique produces a "resolution," or physical division, of the body, anatomy as a practice of thought eventually results in a conceptual "composition" of the body, but I will further discuss the concepts of "composition" and "resolution" later, in the last part of the paper. ${ }^{14}$ Secondly, when speaking of the "specialization" of medicine, we should not confuse a theoretical and purely definitional process of articulating medicine into different parts with an actual and historically determined process of compartmentalization of the medical knowledge into more or less autonomous practices and branches. These two processes have substantial points of contact but do not entirely coincide. The latter also largely depends on social and meta-theoretical factors, such as the way in which a society deals with health and disease as cultural constructs, the demand for professionalized medical practitioners and the constitution and fluctuations of the "medical market", ${ }^{15}$ the interplay between doctors' self-representation and their daily practice, the structure of the curricula of the medical faculties, and the organization of the physical spaces intended for the treatment and observation of ill bodies.

In this paper, three issues will be at stake: 1) Vesalius's views on the partition and specialization of medicine, as we find them expressed in the preface to the De humani corporis fabrica; 2) the relation between such views and Vesal- 
ius's ancient sources; 3 ) the role played by Vesalius's conceptual construction of man's body as a model of reference for representing the "body" of the medical knowledge.

\section{Vesalius against the fragmentation of medicine: the preface to De humani corporis fabrica}

Vesalius shapes the first part of his preface to the De humani corporis fabrica as an attack against fragmentation, which in his eyes is sterile and dangerous, and as an apology for the unity of medical knowledge. ${ }^{16}$ However, beneath the surface of a strongly dichotomous opposition between an attitude of mind that is repeatedly labelled as a cause of ignorance and mistakes and one that is praised as the "true foundation" of medicine, at a closer look Vesalius's argument appears to be more complex and nuanced than one would suspect at first glance, as some interesting lexical choices testify. These choices can be fully appreciated in the very first lines of the dedication to the Emperor Charles: "I believe that no little loss occurs through the too-great separation (nimium diductam divisionem) that has taken place between those disciplines that complement one another for the fullest comprehension of a single art; even much more the very capricious division by practitioners of an art into separate specialities (morosam ad diversos artifices distributionem) so that those who set the limits of the art for themselves tenaciously grasp one part of it while other things which are in fact very closely related are cast aside." ${ }^{17}$ On the one hand, the two targets of Vesalius's polemic seem to be the concept of "separation" rather than that of "partition," and the absence of actual criteria in dividing medicine into disciplines (he refers to a capricious division) rather than the very fact of dividing it. On the other hand, Vesalius depicts medicine as an art whose unity is a consequence of the close relation between parts and whose comprehension depends on the composition of complementary disciplines and skills. Actually, in his preface Vesalius repeatedly refers to a "triple method" of treatment, composed of a regimen of diet, the use of drugs and the use of the hands. Far from engendering a fragmentation of medicine into specialities, this partition provides a practical as well as theoretical definition of the good physician's skills and also of his field of intervention: the practitioner must be versed in every single part of this 'triple' method, as "the successful use of a 
single part depends upon the degree to which they are all combined, for how rare is the sickness that does not immediately require the three instruments of treatment." 18

But the proper method is also presented as a "lost" method, one which has been "miserably distorted" (misere divulta) by generations of bad or false physicians. This is the method the ancient Greek medical sects (respectively, the Dogmatic, the Empirical, and the Methodical) never failed to apply, ${ }^{19}$ as all the three parts of medicine (triplex haec medendi ratio) - argues Vesalius were "equally familiar to the physicians of each sect, and those using their own hands according to the nature of the sickness used no less effort in training them than in establishing a theory of diet or in understanding and compounding drugs." ${ }^{20}$ What happened to medicine after the end of the Greek "Golden Age" was therefore, according to Vesalius, something even more radical than a rush to specialization: it was a process of decadence and degeneration into an epistemological vacuum. This decadence resulted from the threefold method that made up medical practice becoming subject to a phenomenon of fragmentation and, so to speak, of emptying, as the physicians at some point started leaving "the method of cooking and all the preparation of the patients' diet to nurses (custodibus), the composition of drugs to apothecaries (pharmacopolis), and the use of the hands to barbers (tonsoribus)." As far as the procedures of dissection of the human body are concerned, the separation and compartmentalization of duties were even more evident and proved to be absolutely disastrous (Vesalius defines it as a pestilens dispersio). Let us read directly Vesalius's account of such procedures, or better to say of the "detestable" rite (detestabilem ritum) to which anatomy had been reduced, in Vesalius's eyes, after centuries of distorted practice and false theories:

Some conduct the dissection of the human body and others present the account of its parts, the latter like jackdaws aloft in their high chair, with egregious arrogance croaking things they have never investigated but merely committed to memory from the books of others, or reading what has already been described. The former are so ignorant of languages that they are unable to explain their dissections to the spectators and muddle what ought to be displayed according to the instructions of the physician who, since he has never applied his hand to the dissection of the body, haughtily governs the ship from a manual (ex commentario nautam...agit). ${ }^{21}$ 
The rhetoric on which this story is based is one of "loss" (a loss which is, I would say, moral as well as intellectual) $)^{22}$ and "restoration," and for this reason Vesalius's argument openly makes use of history and refers to the Ancients of medicine and their heritage. In fact, the proper method of medicine (as well as the correct partition of medicine into disciplines) is said to be an ancient one, a method which Galen perfectly embodied: the "Prince of medicine after Hippocrates" (post Hippocratem medicinae princeps), ${ }^{23}$ as claimed by Vesalius, "frequently assures us of his pleasure in the employment of his hands, and how zealously (quam studiose) he used them. Indeed, none of the other ancients was so concerned that the treatment made with the hands, as well as that performed by diet and drugs, be handed down to posterity."24 Moreover, Vesalius's description and reprobation of the ex cathedra anatomy lesson develops a theme that was already Galen's, as is testified by a passage of On Anatomical Procedures: "Perched high on a professorial chair a man can say these things to his pupils without being able to instruct them in the actual practice of the Art. For he begins by being ignorant of the parts of the animal organs, and even those thought to be highly expert are acquainted only with the parts clearly visible under the skin." ${ }^{25}$ Finally, the fact that Vesalius's polemic was directly and expressly derived from Galen is confirmed by the presence of the syntagm "ex commentario nautam," which, as has been suggested to me by A. Roselli, cor-

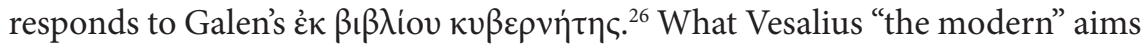
to do, therefore, is not to create a new method "ex nihilo" but just to resuscitate a good practice ${ }^{27}$ - I would say a good Galenic practice - and to re-establish an old concept of the articulation of the medical knowledge (a concept that is assumed to imply unity rather than fragmentation), which had disappeared or been distorted for a long time. But the use Vesalius makes of the Ancients in constructing his argument is far wider than one would suspect at first glance.

\section{The ancient sources of Vesalius's polemic}

Both the theory of the (tri)partition of medicine and the polemic against the unmethodical fragmentation of medicine into various isolated branches of learning are clearly derived from an ancient theoretical/historiographical leitmotif, evidence of which we can find in texts and authors well known to Vesalius, such as Cicero's De oratore $(3,132),{ }^{28}$ Scribonius Largus,${ }^{29}$ Celsus's De 
medicina, ${ }^{30}$ and, in even more complex and subtle terms, Galen's On the Parts of the Medical Techne. In what follows I will focus on Celsus and Galen, casting light on the commonalities and/or the discrepancies between their views on the specialization of medicine and Vesalius's.

a) Celsus. In $₫ 9$ of the prooemium of his De medicina, ${ }^{31}$ Celsus claims that the generations of physicians who came after Hippocrates (i.e. the generations from Diocles to Erasistratus) "practised this art in such a way that they made progress towards diverse methods of treatment" (sic artem hanc exercuerunt ut etiam in diversas curandi vias processerint), and were ultimately responsible for the art of medicine being divided into three parts (in tres partes medicina diducta est): "one being that which cures through diet (una esset quae victu... mederetur), another through medicaments (altera quae medicamentis), and the third by the hand (tertia quae manu)." This division, which is exactly the same one to which Vesalius refers in his preface, provides in Celsus's historiographical account both a theoretical framework for defining and organizing the medical knowledge, its methods and fields of application, and a rhetorical pattern for constructing the discourse on this knowledge, as the internal structure of the De medicina follows exactly the same partition (books I-IV are on regimen, V-VI on pharmacology, VII-VIII on surgery). ${ }^{32}$ Furthermore, just as Vesalius considers the fragmentation of the methods as a sign of the decadence of medicine and praises those practitioners who are versed in all three branches of medical practice, in the same way Celsus on several occasions claims that medicine must be seen as a single art made of interconnected parts, because "all branches of medicine (omnes partes medicinae) are so connected (innexae) together, that it is impossible to separate off any one part completely." ${ }^{33}$ Plurality of methods cannot therefore entail separation of skills, as "both that which treats by dieting has recourse at times to medicaments, and that which combats disease mainly by medicaments ought also to regulate diet"; "one and the same man," Celsus affirms elsewhere, must be able "to undertake all of these treatments (eundem quidem hominem posse omnia ista praestare); and when divisions are made (ubi se diviserunt) - continues Celsus - I praise him who has undertaken the most (eum laudo qui quam plurimum percepit)." ${ }^{4}$ This last statement, which we find in the preface to the two books on surgery, comes after Celsus's historical sketch of the process of professionalization that, according to his judgment, this branch of medicine had experienced "after Hippocrates." 35 
It also stands as a memento, a vibrant warning of the distortions which a discipline like surgery can be subject to, in spite of its increasing importance, if it indulges in uncontrolled and disproportionate specialization.

This aspect of Celsus's argument is substantially different from Vesalius's. The story that Vesalius tells by referring to the "triple method" and its pulverization is one of decadence and prospectively of restoration of the pristine splendour of medicine, which makes his perspective somewhat static: he is not interested in the historical dynamics that caused the correct method to come into being, but provides a somewhat rough juxtaposition, of very great rhetorical effectiveness, between a Golden Age (the lost past of medicine) and a Bronze Age (medicine in the present). By contrast, Celsus's approach to the history of medicine and the constitution of the medical method is pervaded by a strong feeling for complexity, which results in a far subtler dialectic between the historiographical categories of "progress" and "regress" on the one hand, and epistemology-laden key concepts such as "unity," "partition," and "specialization" on the other. ${ }^{36}$ As we have seen, the opposition between a golden and a bronze age is not extraneous to Celsus, but he transposes this dichotomy into a mythistorical plan. ${ }^{37}$ In other words, he contrasts a somewhat mythical lost age, in which men were naturally healthy and medicine was a pre-scientific and universal form of knowledge that offered a readily accessible means of treating wounds and diseases, with an age in which, as a result of the fact that some peoples (the Greeks, and afterwards the Romans) had lost their pristine inclination to good health (a loss that testified to a sort of moral decadence), medicine had widened its range of action and its methods had progressively developed and gained in terms of complexity (in $\$ 5$ of the Prooemium, Celsus speaks of multiplex ista medicina). ${ }^{38}$ Therefore, because of the momentous shift from prehistory to history that medicine is said to have accomplished by virtue of the foundational act of Aesculapius, ${ }^{39}$ the idea of an "evolving knowledge" becomes absolutely central to Celsus's understanding of medicine. All the subsequent phenomena of division and specialization of the medical techne described in Celsus's preface (including the canonical tripartition into regimen, pharmacology, and surgery) should be contextualized in this epistemological/ histori(ographi)cal framework. Without going into details, suffice it here to say that "selective specialisation, fragmentation, sharply circumscribed limitations of healers, and unequal developments within medicine are depicted by Celsus 
as characteristic, if not in all respects desirable, features of the development of post-'primitive' medicine". 40

b) Galen. Let us now turn to Galen's On the Parts of the Medical Techne. The Greek original of this treatise is no longer extant, but we have a Latin version of it by Niccolò da Reggio and a ninth-century Arabic translation that survives in an eleventh-century manuscript of the Aya Sofya collection in Istanbul, which was first studied by Ritter and Walzer in the thirties of the last century. ${ }^{41}$ The treatise was considered spurious by Kühn, who did not include it in his Claudii Galeni Opera Omnia (1821-33), which caused later scholars to neglect it, until Schöne, who published a critical edition of the Latin translation in $1911 .{ }^{42}$ Nevertheless, the Latin version of the text was well known and repeatedly published (both in Niccolo's original and in a revised version of it by the humanist Vettore Trincavelli) as part of the Galenic corpus since the editio princeps of Galen's works of 1490 (published in Venice by Philippus Pincius), at least until René Chartier's edition of 1638 (Operum Hippocratis Coi et Galeni Pergameni, tomus II). ${ }^{43}$ For this reason, it must have been familiar to Vesalius, too. In recent times, $\mathrm{H}$. von Staden has convincingly argued for its authenticity. In this treatise, Galen raises the issue of the division and specialization of medicine by approaching it from the theoretical as well as from the pragmatic and, so to speak, the "sociological" side. ${ }^{44}$ Like that of Celsus, Galen's perspective is characterized by a conceptual tension between unity and division. In spite of the emphasis he places on the interconnectedness of the parts of medicine ${ }^{45}$ and his frequent claims that the knowledge and skills of the "good physician" must not be defective in any aspect of the medical episteme (not to mention philosophy and logic), Galen nevertheless insists on the identification of all the branches into which medicine happened to be divided in Rome in his times.

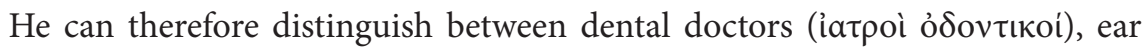

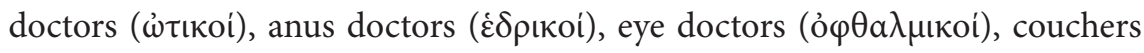

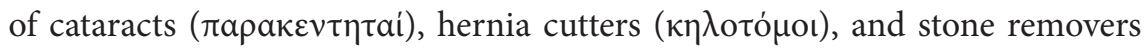
$\left(\lambda_{\imath} \theta\right.$ otónoı). ${ }^{46}$ Moreover, he states that, because of the complexity of the body and the multiplicity of diseases, "it is not inconceivable (non irrationabiliter videbitur) if not only will there be a single specialist to deal with each part of the body individually (aliarum uniuscuiusque corporis partium proprius, ut sint tot medici quot particule), but each of the ailments of each of the parts will have its separate specialist (secundum enim unamquamque passionem erit unus 
medicus)." Before this proliferation of specialities - however real, feared or hypothetical it might have been - Galen's attitude of mind is one of pragmatic and dispassionate consideration of the causes, rather than one of mere rejection of the phenomenon. Of exceptional interest is the link, already noticed by H. von Staden, ${ }^{47}$ that Galen establishes between specialization and massive urbanization: "For, in a small town someone who couches eyes or cuts hernias will not be sustained at all, whereas in Rome and Alexandria, thanks to the great multitude of inhabitants, there are enough people to ensure a livelihood for those who practice any single branch of medicine whatsoever, let alone for those who have more medical competence than that". ${ }^{48}$ This seems to suggest that for Galen, far from being just a symptom of decadence, specialization is somewhat unavoidable and to some extent necessary, even if not desirable. It results from the combination of, and the interplay between, different factors of a professional, technical, and socio-economical kind, each of which is considered to play an active role in shaping and orienting medical practice.

As far as the theoretical/methodological side of Galen's argument is concerned, his views on the division of medicine into parts are of even greater impact, especially if compared with Vesalius'. First of all, a point should be made clear: On the parts of the medical techne does not in any way aim to de-legitimise tout court the theoretical attempts made to determine the constitutive parts of medicine. On the contrary, as is made clear by the dedicatory words of the incipit (De partibus medicative, Juste dilectissime, convenienter mihi videris dubitare, cum alii et alii aliter eas distinguant), this treatise testifies to Galen's commitment to posing, as rigorously and clearly as possible, a question that was considered central to medical epistemology and that had in fact aroused a variety of confused and somewhat unmethodical answers from the other medical writers before him. After a survey of the Dogmatic and Empiricist divisions (some of which I have mentioned above), ${ }^{49}$ Galen starts expounding his own ideas on the parts of medicine from chapter three onwards. I will not go into detail about the various divisions and subdivisions discussed and proposed by him (this work has been excellently done by H. von Staden ${ }^{50}$ ), but I will focus on the analogy between the dissection of the body and the partition of medicine. This analogy, while implying and somehow requiring further divisions and finer distinctions, appears nevertheless to play a key role in the whole conceptual architecture of the treatise. As Galen explicitly says at a certain point of his argument, "a consequence of the body being material for the medical techne is 
that this techne can be split into as many parts as those into which the body can be divided (Quia igitur materia quodammodo est medicative corpus hominis, tot ostendet incisiones hec ars secundum partem, quot et corpus). ${ }^{\prime 1}$ In this way, the object of the medical knowledge - the body - becomes the model in reference to which medicine can in its turn be described as an interconnected system - a coherent body, one could say - of skills, procedures, and practices. ${ }^{52}$ The bodily side of the analogy is based on a progressive distinction, which corresponds to the distinct phases of dissection, between the major parts of the body (head, chest, belly, and limbs in the Arabic version, but head, hands, and feet in Niccolòs translation ${ }^{53}$ ), the "instrumental organs" - i.e., those organs (like the eyes, ears, heart etc.) responsible for a bodily activity - and the "perceptible elements." These are the body's smallest perceptible parts, which Galen elsewhere describes in great detail as being composed of the imperceptible "first natural elements" (earth, water, air, fire), as homoeomerous and uniform (we are actually speaking of fibres, membranes, bones, flesh, cartilages, ligaments etc.), and as constituent parts of the instrumental organs. ${ }^{54}$ The techne side of the analogy allows partitions and sub-partitions of medicine to be established, by directly deriving them from the distinction between instrumental organs and perceptible elements: ${ }^{55}$ so, if the eye is an instrumental organ, the relation between the art of treating eye diseases and the medical techne as a whole will be the same as the one that exists between the eye and the body as a whole. Similarly, as the eye is found to be composed of several perceptible elements, so the art of treating eye diseases can in turn be divided into a number of "elemental" technai, or basic skills and activities necessary for treatment. The logic of this twofold dissection - one aspect of which results in a material anatomy of the body, the other in an intellectual anatomy of medicine - has been grasped and lucidly expressed by H. von Staden, when he claims that in Galen's argument "dissection proceeds not only by moving from larger to increasingly smaller pieces of anatomical (and technical) territory but also by determining functional differentiae and by distinguishing between functional levels."56 


\section{Anatomy as epistemology: the theoretical specificity and historical implications of Vesalius's views on specialization}

After this brief recognition of the two most articulated and influential ancient accounts of the division and specialization of the medical techne, accounts with which Vesalius was certainly acquainted, we are now ready to get a deeper insight both into Vesalius's own views on the unity and divisibility of medicine and into the relationships he established with the ancient models with respect to this question. I have already stressed that Vesalius's way of dealing with the "essential tension" between the unity and divisibility of medicine is definitely less subtle and more simplistic than that of both Celsus and Galen. But what is even more interesting to my eyes is that Vesalius, the man who aimed to restore anatomy's lost dignity by returning to the purest experiential meaning of Galen's anatomical teaching, was not proposing a dissection-based partition of medicine that followed his ancient master's example. In fact, Vesalius assigned a clear epistemological primacy to anatomy when he claimed that "since it includes the description of man (quum hominis historiam complectatur), it ought rightfully to be considered the 'very beginning' and 'solid foundation' of the whole art of medicine (firmissimumque totius medicae artis fundamentum, ac constitutionis initium iure habenda sit)." However, in Vesalius this epistemological primacy does not engender, at least not explicitly, a "meta-anatomical use" and thus an actual "epistemologization" of dissection (as seems to be the case in Galen), in that the "body" of medicine is said to be founded upon anatomy, not to derive its structure and internal differentiation directly and immediately from the image of the dissected body. ${ }^{57}$

Various reasons can be adduced to explain such a substantial difference between Galen and Vesalius. Firstly, while Galen aimed at a systematization of medicine as an anatomy-based philosophical science of health and disease, Vesalius's discourse was instead narrowly focused on anatomy: for this reason a number of general issues of a meta-theoretical and definitional kind (like that concerning the correct way of dividing medicine) proved somewhat extraneous to the research core of the latter. Secondly, both Galen's emphasis on the partition of medicine and the use he makes of dissection as a logical tool for enchaining sequences of distinctions, divisions, and subdivisions would not have been possible or even thinkable if not within the framework of the diairesis-based way of reasoning that was typically Galen's (a paradigmatic example 
of which is provided by the argumentative structure of the Ars medica ${ }^{58}$ ) and that served as one of the main bases on which his entire medical-philosophical system was built. Thirdly, Galen perceived anatomy as an authoritative and advanced knowledge with a long-established tradition; he perceived himself as a man who had brought anatomy to its highest peaks by developing all its technical/methodological and theoretical potentialities. His use of dissection as a key to the logic and the epistemology of medicine was no doubt a clever move that belonged within such a positive scenario. Vesalius, for his part, was engaged in resurrecting and revitalizing a knowledge that he perceived as having fallen into decay. Consequently, his proposed task - to bring anatomy back "from the region of the dead" and to allow it "to raise its head from profound gloom" (Fabrica, preface) - was in a way more basic, although titanic and not less ambitious, than Galen's. Fourthly, and perhaps most importantly, the logic intrinsic to the De humani corporis fabrica is one that intertwines "composition" and "resolution" of the body. This is an important point to focus on, as Vesalius has been traditionally considered the "champion" of resolution - that is, of an anatomical discourse based on analytical representations of functional systems. D. Laurenza, for example, has contrasted Vesalius's anatomical descriptions with Leonardo's synthetical anatomical drawings, arguing that the former followed the order of dissection and emphasized "the primacy of the particular," while the latter ultimately aimed at a "topographic" account of the compound parts of the body (arm, leg, head etc.) and their harmonic arrangement. ${ }^{59}$ This can certainly be considered true, as long as one does not absolutize such a distinction..$^{60}$ As a matter of fact, the adherence of Vesalius's discourse to the order of dissection proves to be "ideal" rather than "actual," or, to put it in other terms, "conceptual" rather than "practical." The passage from the hand to reasoning - that is, from "cutting" as a material practice to "dissecting" as practice of thought - implies a mediation, and in some way imposes an inversion, between analysis and synthesis, resolution and composition. The same descriptive sequence which topographically belongs within the order of analysis and resolution (as it breaks spatial unities of the body) is functionally ascribable to the order of synthesis and composition, as it causes other elementary and otherwise hidden units such as the bone- or muscle-system to emerge as a coherent whole. ${ }^{61}$ In order to clarify my view on this crucial point, I will quote and briefly discuss a passage of Vesalius's Preface to the Epitome: 
Actually, I assumed that it was not necessary here to give proofs of our negligence in learning Anatomy, which is the basis and the foundation of the medical art in its entirety (totius medicae artis basi ac fundamento), as well as of how indispensable (pernecessaria) be the knowledge of the parts of the human body for us who are engaged in medical practice. For...the cognition of these parts plays a key-role in the treatment of diseases." ${ }^{2}$

To Vesalius's eyes, dissection represented the only possible foundation of anatomical knowledge and the only reliable source of experience, as seems to be confirmed by the manner in which he emphasizes the idea of the existence of "parts of the body." In spite of this, a clear distinction is always maintained in his oeuvre between the practical and the conceptual order of dissection - that is, between dissection as a technique and dissection as a form of anatomical reasoning - which has important consequences for the definition of Vesalius's concept of "part." While dissection proceeds from the exterior to the interior and from the largest to the smallest, Vesalius's account of the body in the Fabrica follows exactly the opposite direction, proceeding from the interior to the exterior, from the most "elementary" and "homogeneous" parts (bones, muscles, ligaments, nerves, veins, arteries) to those of greater complexity and functional specialization (organs and "apparatuses"). In the words of G. Canguilhem, "le démontage operé par le discours de l'anatomiste ressemble moins à une division et dispersion de parties qu’à léclairage progressif d'un ensemble." 63 This descriptive scheme, it is true, is the same that Galen identifies as the ideal sequence to learn anatomy (actually, the structure of the De humani corporis fabrica realizes a sequence that in Galen remains "ideal," as none of the anatomical treaties of the latter strictly follow it), ${ }^{64}$ but when defining the parts of medicine Galen does apply the order of dissection instead of the order of anatomy as narrative. Now, the most evident signs of this epistemological inversion are the paucity of chapters of Vesalius's anatomical treatise devoted to describing the technical procedures of dissection (they are summarized in the final chapters of books V, VI, VII), and, above all, Vesalius's choice of entitling his oeuvre De humani corporis fabrica. His was in fact the first anatomical treatise since Mondinus's Anothomia not to contain the words "anatomia" or "dissectio" in its title, ${ }^{65}$ these having been replaced by the notion of "fabrica," imported directly from Cicero's De Natura Deorum ${ }^{66}$ - through which Vesalius once again seems to express and reshape a Galenic concept, that 


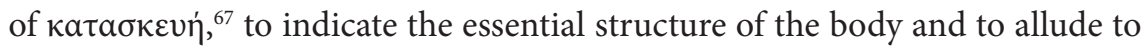
the natural "fabrication" and the intellectual "reconstruction" of the body at the same time.

\section{Conclusion}

What consequences, if any, did the reform of the anatomical mentality that Vesalius inaugurated have on the organization of the "body of medicine"? An exhaustive answer to this question would far exceed the limits and scope of this paper. I will limit myself to a couple of brief considerations, which may offer material for future investigations. It is my impression that, in following a functional/stratigraphical criterion rather than a merely spatial/local one, Vesalius's anatomical account decisively contributed to remodelling the idea of the unity of the body, which in fact started to be seen as derived from a transversal system of unities; that is, of stratified parts (bones, muscles, nerves, ligaments, veins, tissues) and of distinct but interdependent groups of organs supplying all the physiological activities. The "unity of the body" definitively ceased to be a self-evident phenomenological datum and started changing into a derived concept scientifically graspable only by means of serialized dissections. Actually, to the eyes of the anatomist the unity of the body can even appear to be the result of a technical procedure of (re)articulating the skeleton after dissection. ${ }^{68}$ As Vesalius remarks in the opening chapter of book VI of the Fabrica, "you may display the entire human structure to others in the same body with economy of cadavers, although I believe it impossible for you to learn everything exactly for the first time by dissection of only one body". ${ }^{99}$ While not directly implying or suggesting the partition of the medical field into specialities, Vesalius's method seems therefore to have posed a theoretical premise - necessary, but of course insufficient in itself - to explain the rise of the first apparatus- and organ-based clinical specialities, in that it smoothed the way for a localist organic thinking and disentangled the "unity of the body" as a concept from the "unity and singularity of the body" as a constitutive condition of the anatomical and clinical experience. ${ }^{70}$ These specialities, which saw the light of day long after Vesalius (they emerged on a large scale between the end of the eighteenth and the beginning of nineteenth centuries), represented only one of the institutional and organizational outcomes of the 
anatomoclinical reform of medicine. Other specialities such as paediatrics, obstetrics, and neurology arose at that time as the result of criteria of partition and in response to needs that had not specifically or exclusively to do with anatomy. ${ }^{71}$ It is worth saying, however, that the whole process of specialization that nineteenth-century clinical medicine experienced would perhaps have been impossible if a substantial unification of medicine and surgery had not occurred among Paris medical faculty and then in the rest of the Western world, as a consequence of the re-organization that involved both medical schools and teaching hospitals. ${ }^{72}$ The fact that this unification put in place the most essential condition posed by Vesalius for the renaissance of medicine the end of the separation between medical and surgical practice - gives us an idea of the complexity and tortuousness of the historical process by which the "body" of modern medicine has been shaped, and of how essential, even if not always obvious and immediately appreciable, Vesalius's contribution to this process was. But a historical-epistemological investigation into the reception of Vesalius's anatomical project in nineteenth-century medicine and its influence on the rise of the anatomo-pathological paradigm still remains a desideratum of the history of medicine. With this study I hope to have paved the way for, and to have provided the Renaissance prolegomena of, such an investigation.

\section{Notes}

1. I am most grateful to the Alexander von Humboldt-Stiftung for funding this research as part of the research programme "Medicine of the Mind, Philosophy of the Body," directed by Prof. Philip van der Eijk. This paper also belongs within the research programme ANR-Philomed "La refonte de l'homme. Découvertes medicale et philosophie de la nature humaine" (Réf. Projet: JCJC-09-0145-01). The final version of this paper was brought to completion during a research stay at the "Institut d'histoire de la médecine et de la santé publique" (IUHMSP) of the University of Lausanne, where I worked as "chercheur invité" in October-November 2009 and found a most congenial research environment. I am most grateful to the director of the Institute, Vincent Barras, for his kind and generous invitation, and to the whole staff of the Library of History of Medicine (and especially to Dr. Daniela Vaj) for welcoming me so warmly and for offering me the most profitable conditions of work. An earlier draft of this paper has been read by Vincent Barras, 
Philippe Mudry, Donald Beecher, Amneris Roselli, Maria Michela Sassi, Philip van der Eijk, Hélène Cazes, Florence Bourbon, whose comments and remarks significantly contributed to its improvement. I also thank the two anonymous referees for their useful comments. Of course, I am the only one responsible for any faults or mistakes.

2. Vesalius's De humani corporis fabrica was first published in 1543 in Bâle by Oporinus. A second revised edition appeared in 1555. For an introductory analysis of the Fabrica and a survey of Vesalius's life and work see C. D. O'Malley, Andreas Vesalius of Brussels (1514-1564) (Berkeley, Los Angeles: University of California Press, 1964) and the introductory essay by V. Nutton: "Introduction" to Andreae Vesalii De humani corporis fabrica, trans. D. Garrison \& M. Hast @Northwestern University 2003, http://vesalius.northwesternedu.

3. Which is different from saying that Vesalius was the "father" of modern anatomy or even of modern medicine tout court. Such rhetoric of paternity had been already questioned by G. P. Arcieri in "Leonardo da Vinci e Andrea Vesalio negli studi anatomici. Perchè Vesalio non può chiamarsi il padre dell'anatomia”, in Rivista Storica delle Scienze Mediche XXXVIII (1947), pp. 182-215, and now has been definitively proven as historically false and misleading by R. Mandressi's studies (see Mandressi's Le regard de l'anatomiste: dissections et inventions du corps en Occident (Paris: Seuil, 2005) and "Métamorphoses du commentaire: Projets éditoriaux et formation du savoir anatomique au XVI ${ }^{e}$ siècle”, in Gesnerus 62 (2005), pp. 165-85.

4. On the one hand, a number of studies (Mandressi 2005, just to mention one of the most influential) have proved that Vesalius' attitude toward Galen was extremely complex and in fact combined adhesion (especially to Galen's physiology) and criticism, emulation and innovation. See A. Carlino, La fabbrica del corpo. Libri e dissezione nel Rinascimento (Torino: Einaudi, 1994, English trans.: Books of the body: anatomical ritual and Renaissance learning, Chicago: University of Chicago Press, 1999); A. Cunningham, The anatomical renaissance: the resurrection of the anatomical projects of the ancients (Aldershot: Ashgate, 1997); R. K. French, Dissection and vivisection in the European Renaissance (Aldershot: Ashgate, 1999); J. Pigeaud, Préface à Andreae Vesalii De humani corporis fabrica (Paris, Torino: Aragno Editore, 2001), pp. vii-lii; R. Mandressi, Le regard de l'anatomiste. By way of example, see Mandressi, Le regard de l'anatomiste, p. 180: "aussi la critique de Vésale n'est pas une entreprise de démolition du galénisme, mais d’amendement minutieux de son versant anatomique - la physiologie de Galien n'est nullement 
remise en cause dans la Fabrica." On the other hand, we ought not to forget that also among the so-called "Pre-Vesalian" anatomists we find very different approaches to Galen, ranging from quite passive acceptance to a more critical and problematic tone. This is the case, for example, of Berengario da Carpi (who had commented Mondinus' Anothomia, see below n. 7). See L. R. Lind, Jacopo Berengario da Carpi, A short introduction to anatomy (Isagogae breves), translated with an introduction and historical notes (New York: Kraus Reprint Co., 1969), pp. 3-27; R. K. French, "Berengario da Carpi and the use of commentary in anatomical teaching," in A. Wear, R. K. French, I. M. Lonie, ed. The medical Renaissance of the sixteenth century (Cambridge: Cambridge University Press, 1985), pp. 42-74; and Mandressi, "Métamorphoses du commentaire," pp. 167-175 (the latter has stressed how Berengario's works served as an epistemological preparation to Vesalius' Fabrica). Neither Niccolò Massa, who however was persuaded of the overall validity of the Galenic doctrine, abstained from selective criticisms (see C. D. O’Malley, "Niccolò Massa," in Physis XI (1969), pp. 459-460). By contrast, Jacobus Sylvius, one of Vesalius's teachers in Paris, used to say that the discrepancies between Galen's teaching and the results of observation had to be explained by postulating a change of human nature. Nevertheless, the role played by Sylvius in Renaissance anatomy cannot be considered as one of mere conservation (especially by reason of his work as translator of Galen's works), as brilliantly argued by C. E. Kellett, "Sylvius and the reform of anatomy," in Medical History 5 (1961), pp 101-116.

5. French, Dissection and vivisection, p. 144.

6. N.G. Siraisi, "Vesalius and the reading of Galen's teleology," in Renaissance Quarterly 50.1 (1997), pp 1-37, 2.

7. Mondino dei Luzzi (1270 ca.-1326) is believed to be the first European who dissected the human body publicly. He was also the first medieval anatomist to give an account of the preparation for and the process of human anatomical dissection, and to provide some knowledge of physiology and surgical anatomy. The editio princeps of his Anothomia is dated 1478, its first association with Ketham's Fasciculus Medicinae is dated 1495, but we have editions of Mondino's Anothomia as late as 1580, which testifies to the importance of Mondino's text as work of reference for anatomical studies for more than two centuries. In fact, the method followed by Mondino was that of the three-venter division (belly, chest, head) for both the dissection and the understanding of the human body. See L. R. Lind, Studies in preVesalian Anatomy (Philadelphia: American Philosophical Society, 1975), p. 6; Cun- 
ningham, The Anatomical Renaissance, pp. 42-54, Carlino, La fabbrica del corpo, pp. 16-25.

8. On Niccolò's work as translator of Galen's works see L. Thorndike, “Translations of works of Galen from the Greek by Niccolò da Reggio (c. 1308-45)," in Byzantina Metabyzantina I (1946), pp. 213-235. However, as has been pointed out by R. K. French (in "De Juvamentis Membrorum and the reception of galenic physiological anatomy," in Isis 70 [1979], pp 96-109), the De Juvamentis Membrorum "remained much more popular than De usu partium until well into the Renaissance. There are many more manuscripts extant of the shorter work, and two hundred years after Nicholas of Reggio produced the full text from the Greek, De Juvamentis Membrorum was being printed alongside it in the collected works of Galen, for example, in the edition of Pavia, 1515-1516 and that of Venice, 1528” (p. 97).

9. Here are the contents and structure of Galen's De usu partium: book I: hand; II: arm; III leg; IV-V; organs of nutrition; VI-VII: organs of respiration; VIII-IX common parts of head, neck, shoulder and the back; X: eyes; XI: face; XII-XIII: back and shoulder; XIV-XV: genitals; XVI; elements common to the whole body (arteries, veins, nerves); XVII: final praise of the harmony and usefulness of the parts. As it is easily recognizable, apart from the exposition of the hand structure and function, the whole structure of the treatise provides the model for the "bottom up sequence" which will be followed by anatomists in dissecting the human body until Vesalius.

10. A first Latin version of Galen's De anatomicis administrationibus was given by the Byzantine Demetrius Chalcondyla between 1491 and 1511, but this version had a limited circulation. Moreover, it was criticised as incomplete and unsatisfactory by Berengario da Carpi, who cited it in the preface of his Libri anatomici (Bologna, 1522), containing the Latin version of five Galenic texts. On Chalcondyla's Latin translation of De anatomicis administrationibus see S. Fortuna, "I Procedimenti anatomici di Galeno e la traduzione latina di Demetrio Calcondila," in Medicina nei secoli 11 (1999), pp. 9-28, and Mandressi, "Métamorphoses du commentaire," p. 183.

11. De anatomicis administrationibus, tr. Johannes Guintherius Andernacus, fol. Paris: S. de Colines, 1531. See R. J. Durling, "A chronological census of Renaissance editions and translations of Galen," in Journal of the Warburg and Courtauld Institutes 24 (1961), pp. 230-305, 257. Some years after, on the occasion of the Juntine edition of Galen's works of 1541-42, Vesalius was entrusted with the revision of 
Guinther's translation of On Anatomical Procedures. See Mandressi, "Métamorphoses du commentaire," p. 179.

12. It does not, of course, imply that Vesalius's De humani corporis fabrica merely conforms to Galen's De anatomicis administrationibus. We are in fact in the presence of a complex phenomenon of active reception and variation of the model, as is made clear by a comparison of the table of contents of the two works. This is the table of contents of Galen's De anatomicis administrationibus: book I: muscles of the arm and claim for the study of the simple parts (muscles, arteries, veins, nerves); II: muscles of the leg; III: other anatomical components of the limbs (nerves, vessels); IV-V: muscles of other regions of the body; VI: organs of nutrition; VII-VIII: organs of respiration and thorax; IX: brain and marrow. And here is the table of contents of Vesalius's Fabrica: book I: bones; II: ligaments and muscles; III veins and arteries; IV nerves; V: organs of nutrition and generation; VI: heart and thorax; VII: brain and sense organs. Two years after the publication of Vesalius's masterwork, Charles Estienne published his De dissectione partium corporis humani libri tres, whose order of exposition presents interesting analogies with, but also substantial differences from, the structure of the De humani corporis fabrica. As is the case with the De humani corporis fabrica, Estienne's anatomical treatise opens with a description of the parts that provide the body's shape and foundations (Liber II, Proemium: quae partes solidiores et exteriores quaeque machinam potissimum constituebant): bones, cartilages and ligaments, nerves, membranes, muscles and tendons, glands, veins and arteries, skin; book II, instead, is devoted to the description of the three venters (abdomen, chest, and head), i.e. those internal parts quae maxime pertinent ad vitam, and of their faculties, quibus incolumes vivimus (liber II, Proemium). The part of Estienne's account which has no parallel in Vesalius' work is book III, where French anatomist focuses on single parts of the human body from which proves most evident the perfection and singularity of man in comparison with animals (liber III, Proemium: membrorum singulae partes in quibus perfectiorem videas atque absolutiorem nostri corporis structuram, quam quae belluarum est aut animalium rationis expertium).

13. Katharine Park has devoted some studies to medieval and early modern practices of manipulation of the dead body that, although defined as "anatomies," had nothing to do with the medical dissecting technique, as they were in fact practices of division or even dismembering, evisceration and preparation of the corpse for embalming and other rituals (like those connected with the burial of dead kings, ecclesiastical hierarchies, as well as aristocrats and notables) or for devotional 
practices (such as the production of reliquiae sanctorum). See Katherine Park, "The criminal and the saintly body: autopsy and dissection in Renaissance Italy," in Renaissance Quarterly 47 (1994), pp. 1-33, and "The life of the corpse: division and dissection in late medieval Europe," in Journal of the History of Medicine and Allied Sciences 50 (1995), pp. 111-32. On this matter see also E. A. R. Brown, "Death and the human body in the later Middle Ages: the legislation of Boniface VIII on the division of the corpse," in Viator 12 (1981), pp. 221-70; R. C. Finucane, "Sacred corpse, profane carrion: social ideals and death rituals in the later Middle Ages," Mirrors of mortality: studies in the social history of death, ed. J. Whaley (London: Europa Publications Ltd., 1981); C. Bynum Walker, Fragmentation and redemption: essays on gender and the human body in medieval religion (New York: Zone Books, 1991), pp. 239-97. On medieval embalming procedures see also E. von Rudloff, Über das Konservieren von Leichen im Mittelalter: ein Beitrag zur Geschichte der Anatomie und des Bestattungswevens (Freiburg im Breisgau: Karl Henn Verlag, 1921).

14. Along with "anatomy as a technique and a manual practice" and "anatomy as narrative," N. G. Siraisi has argued that two other metaphorical and in fact metaanatomical uses of anatomy as a method of thought were characteristic of Renaissance medicine (and more in general, of Renaissance culture): "anatomy as form of textual analysis" (and 'anatomy as a form of histori(ographi)cal inverstigation and learning.'). See Siraisi, "Vesalius and the reading of Galen's teleology": "in principle, though certainly by no means always in practice, the new anatomy demanded that anyone who could dissect a cadaver should also be capable of dissecting an ancient Greek anatomical text, and that anyone who wished to discuss an anatomical text should also be capable of dissecting a cadaver") (p. 2). See also N. G. Siraisi, "Anatomizing the past: physicians and history in Renaissance culture", in Renaissance Quarterly 53 (2000), pp 1-30, and History, medicine, and the traditions of Renaissance learning (Ann Arbor: The University of Michigan Press, 2007) pp. 23-133 and 261-68.

15. On aspects of the "medical market" and the actual conditions of medical practice in the Renaissance see N. G. Siraisi, Medieval and early Renaissance medicine. An introduction to knowledge and practice (Chicago, London: University of Chicago Press, 1990), pp. 17-47; K. Park, "Country medicine in the city marketplace: snake handlers as itinerant healers", Renaissance Studies 15.2 (2001), pp. 104-120; M. A. Katritzky, "Marketing medicine: the image of the early modern mountebank", Ren- 
aissance Studies 15.2 (2001), pp. 121-153; I. Maclean, Learning and the market place. Essays in the history of the early modern book (Leiden: Brill, 2009).

16. See L. Edelstein, "Andreas Vesalius, the humanist," in Bulletin of the History of Medicine 14 (1943), pp 547-561, republished in L. Edelstein, Ancient Medicine, ed. by O. Temkin \& C. Lilian Temkin (Baltimore, London: The Johns Hopkins University Press, 1967), pp. 441-454, 446.

17. Vesalius, De humani corporis fabrica libri septem, Basileae 1543, Praefatio, fol. 2r: “...tamen haud mediocre dispendium quoque adferre arbitror, nimium diductam disciplinarum, quae uni cuipiam arti absolvendae famulantur divisionem, et multo adhuc magis eius artis exercitiorum adeo morosam ad diversos artifices distributionem, ut qui artis scopum sibi praefixerunt, unam eius partem ita complexentur, ut caeteris quae ipsum maximopere spectant, et ab illo seiungi nequeunt, relictis, nihil unquam egregium praestent, ac propositum finem nunquam attingentes, a vera artis constitutione perpetuo declinent" (English transl. O'Malley, Andreas Vesalius of Brussels, p. 317).

18. Vesalius, Fabrica, Praefatio, fol. 2v (transl. O’Malley, Andreas Vesalius of Brussels, p. 318): "However, most august Emperor Charles, I certainly do not propose to give preference to one instrument of medicine over the others, since the aforesaid triple method of treatment can in no way be disunited and the whole of it belongs to the one practitioner (quum triplex dicta auxiliorum ratio minime disiungi possit, et tota ad unum artificem attineat); and that he may employ it properly all parts of medicine have been equally established (omnes medicinae partes ex aequo ita constitutae parataeque sint) so that the successful use of a single part depends upon the degree to which they are all combined (ut singula eo felicius in usum referantur, quo quis cumulatius omnia invicem iungat), for how rare is the sickness that does not immediately require the three instruments of treatment."

19. Vesalius, Fabrica, Praefatio, fol. 2r (transl. O’Malley, Andreas Vesalius of Brussels, p. 317): "Once there were three medical sects, that is, Dogmatic, Empirical, and Methodical, but their members consulted the whole art as the means of preserving health and driving away sicknesses. All the thoughts of each sect were directed toward this goal and three methods were employed (triplici auxiliorum instrumento utebantur): The first was a regimen of diet, the second the use of drugs, and the third the use of the hands (primum victus fuit ratio, secundum omnis medicaminum usus, tertium manus opera). Except for this last, the other methods clearly indicate that medicine is the addition of things lacking and the withdrawal of su- 
perfluities; as often as we resort to medicine it displays its usefulness in the treatment of sickness, as time and experience teach, and its great benefit to mankind."

20. Vesalius, Fabrica, Praefatio, fol. 2r: "Triplex haec medendi ratio, cuiuscunquae sectae medicis aeque erat familiaris, ipsique proprias manus pro affectuum natura curationi accommodantes, non minorem industriam in illis exercendis impenderunt, quam instituendae victus rationi, aut medicamentis dignoscendis, ac componendis” (transl. O’Malley, Andreas Vesalius of Brussels, p. 317).

21. Vesalius, Fabrica, Praefatio, fol. 3r: "tantum abest, ut difficillimam abstrusissimamque artem manu ipsis traditam, id hominum genus nobis asservaret, utque haec pestilens curativae dispersio detestabilem ritum in Gymnasiis non inveheret, quo alii humani corporis sectionem administrare, alii partium historiam enarrare consueverunt. His quidem graculorum modo, quae nunquam aggressi sunt, sed tantum ex aliorum libris memoriae commendant, descriptave ob oculos ponunt, alte in cathedra egregio fastu occinentibus: illis autem adeo linguarum imperitis, ut dissecta spectatoribus explicare nequeant, atque ex physici praescripto ostendenda lacerent, qui manu corporis sectioni nunquam adhibita, tantum ex commentario nautam non sine supercilio agit". (transl. O'Malley, Andreas Vesalius of Brussels, pp. 319-320). On the iconography of dissection before Vesalius's reformation see Carlino, La fabbrica del corpo, pp. 15-39 and Cunningham, The Anatomical Renaissance, pp. 37-87.

22. A loss of this kind being perfectly consistent with the humanist bias against the Middle Ages, which was seen as the time of darkness and the decline of Western civilization (see Edelstein, pp. 447-49).

23. The definition of Galen as the "Prince of Physicians" and that of Hippocrates as the "Father of Medicine" become canonical in Renaissance medicine, as has been showed by H. King, "The power of paternity: the father of medicine meets the prince of physicians," in ed. D. Cantor, Reinventing Hippocrates (Aldershot: Ashgate, 2002), pp. 21-36.

24. Vesalius, Praefatio, fol. 2r: “...crebro inculcat quantum manus artificio oblectatus sit, quamque studiose id cum caeteris Asiae medicis exercuerit. Immo veterum nullus non aeque attente curationem quae manu fit, atque eam quae victu ac medicamentis perficitur, posteris tradidisse videtur" (transl. O’Malley 1964, p. 317).

25. (II, 3, II,289 Kühn = p. 187 Garofalo, English trans. Singer: De anatomics administrationibus libri novem, in Claudii Galeni Opera Omnia, ed. C.G. Kühn, Leipzig 1821-1833, vol. II, pp. 215-731; De anatomicis administrationibus libri qui supersunt novem, ed. I. Garofalo tom. I libros I-IV continens, Napoli 1986, t. I, 1. On 
anatomical procedures (I-IX 6), English trans., introduction, and commentary by

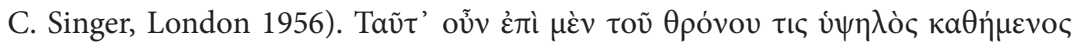

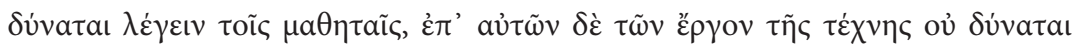

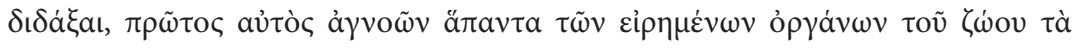

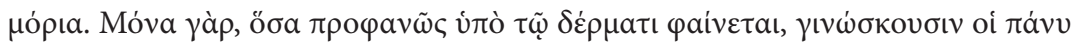

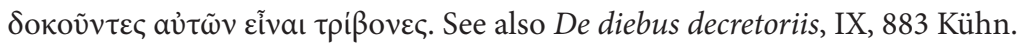

26. Galen, De compositione medicamentorum per genera libri VII, XIII,605 K: عَ̈ı $\delta \grave{\varepsilon}$

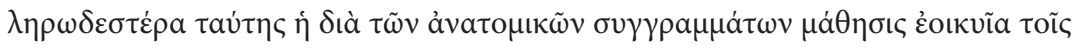

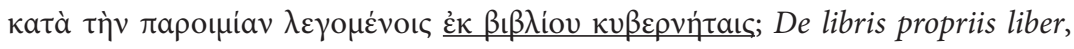

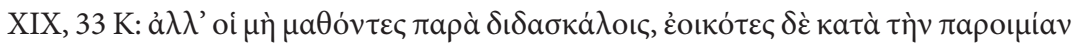

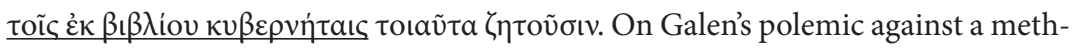
od of learning medicine and anatomy exclusively (or primarily) from books see

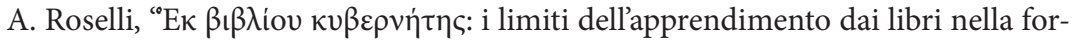
mazione tecnica e filosofica (Galeno, Polibio, Filodemo)," in Vichiana 4.1 (2002), pp. 35-50, whom I thank for bringing my attention to the existence of this analogy between Galen and Vesalius.

27. Cunningham speaks of the "resurrection" of the anatomical project of the Ancients as well as (p. 88) of the "revival" of Galenic anatomy (cf. Edelstein, p. 444).

28. Pigeaud, pp. xviii-xxvi, has put forward illuminating considerations on the influence exerted by classical and especially Cicero's Latin on Vesalius's prose, an issue which is also raised by Edelstein, p. 442-44.

29. Compositiones, Ep. 6 (p. 3.6-11 Sconocchia): etenim quasi per gradus quosdam medicina laborantibus succurrit. Nam primum cibis ratione aptoque tempore datis temptat prodesse languentibus; deinde, si ad hos non responderit curatio, ad medicamentorum decurrit vim; potentiora enim haec et efficaciora quam cibi. Post, ubi ne ad haec quidem cedunt difficultates adversae valetudinis, tunc coacta ad sectionem vel ultimo ad ustionem devenit.

30. As Edelstein, p. 442 n. 3, has argued, "Celsus, whose work De medicina, for Vesalius as well as for other Renaissance authors, was the most important source of their new medical terminology, was the only ancient author to apply the rules of Ciceronian 'Kunstprosa' to the composition of medical writings," which makes him Vesalius's natural model of reference for matters of style. See also Singer, The evolution of anatomy: a short history of anatomical and physiological discovery to Harvey (New York: Knopf, 1925), pp. 104, 117.

31. Pr. 9 (p. 18.17-20 Marx = p. 16 Mudry = I, p. 4 Serbat: Celsus, A. Cornelii Celsi quae supersunt, ed. F. Marx, CML I, Leipzig/Berlin 1915; La préface du De medici- 
na de Celse, texte, traduction et commentaire par Ph. Mudry, Bibliotheca Helvetica Romana (Institut Suisse de Rome), XIX, 1982; De la médecine (livres I-II), texte établi et traduit par. G. Serbat, tome I [Paris: Les Belles Lettres, 1995]). As pointed out by $\mathrm{H}$. von Staden, Celsus' prooemium to his De medicina, probably written in the first decades of the first century CE, represents "the earliest surviving attempt at a comprehensive 'history' of medicine", marking a substantial difference with previous medical doxographies. See von Staden, “Celsus as historian?," in $\mathrm{Ph}$. J. van der Eijk (ed.), Ancient histories of medicine: essays in medical doxography and historiography in classical Antiquity (Leiden, Boston, Köln: Brill, 1999), pp. 251-294, 251. Our understanding of Celsus's prooemium has enormously benefited from the magisterial work done by Philippe Mudry (Mudry, La préface du De medicina de Celse, see especially pp. 45-76, with a commentary on the $\$ \$ 1-11$ of the prooemium, which represents the general introduction to the whole oeuvre, while $\$ \$ 12-75$ are an introduction to the four books on regimen). On Celsus's prefaces (in book V we find a prooemial history of pharmacology, in book VII a history of surgery) see also L. Zurli, "Le praefationes nei Libri VIII De medicina di A. Cornelio Celso," in C. Santini, N. Scivoletto, ed., Prefazione, prologhi, proemi di opere tecnico-scientifiche latine, vol. I (Roma: Herder, 1990), pp. 295-337.

32. It is probable that the eight books of De medicina constituted books 6-13 of Celsus's Artes (see von Staden, Celsus as historian?, p. 251, n. 3).

33. Book 5, pr. 2 (p. 190.13-16 Marx): "This before all things it is well to recognize, that all branches of medicine are so connected together, that it is impossible to separate off any one part completely (omnes medicinae partes ita innexae sunt, ut ex toto separari non possint), but each gets its name from the treatment which it uses most (sed ab eo nomen trahant, a quo plurimum petunt). Therefore, both that which treats by dieting has recourse at times to medicaments, and that which combats disease mainly by medicaments ought also to regulate diet, which produces a good deal or effect in all maladies of the body". Cf. Scribonius Largus, Compositiones, 200 (p. 92.11-12 Sconocchia): "implicitas medicinae partes inter se et ita conexas esse ut nullo modo diduci sine totius professionis detrimento possint."

34. Book 7 pr. 5 (p. 302.8-10 Marx).

35. Book 7 pr. 3 (p. 301.15-17 Marx): ...deinde posteaquam [scil. after Hippocrates] diducta ab aliis habere professors suos coepit. On Celsus's conception of the tripartition of medicine see Mudry, La préface du De medicina de Celse, pp. 66-68, who remarked how Celsus linked the constitution of surgery as an autonomous branch of medical knowledge to the rise of a body of literature exclusively devoted to sur- 
gical issues (the same explanation, remarks Mudry, is given by Celsus to account for the separation of medicine and philosophy). Manetti-Roselli ("Il ruolo della tradizione nei libri chirurgici di Celso," in G. Sabbah, Ph. Mudry, ed., La médecine de Celse. Aspects historiques, scientifiques et littéraires, Centre Jean Palerne, Mémoires XIII [Saint-Etienne: Université de Saint-Etienne, 1994], pp. 103-121) and von Staden (Celsus as historian?, p. 290) have provided strong textual evidence of Celsus's exceptional acquaintance with the surgical treatises of the Hippocratic Collection (namely, De officina medici, De vulneribus in capite, De fractures, De articulis, Mochlicon). On medical specialization (and especially on the specialization of surgery) in Antiquity see M. Michler, Das Spezialisierungsproblem und die antike Chirurgie (Bern: Huber, 1969).

36. See Mudry, La préface du De medicina de Celse, p. 47: "Celse envisage l'histoire de la médecine, considérée rétrospectivement comme une progression [...] Cette progression ne doit pas être comprise comme signifiant un progrès au sens où on l'entend aujourd'hui, c'est-à-dire comme marquant une amélioration qualitative de la médecine d'une étape à l'autre de son développement [...] Le développement de la médecine est fait pour Celse de la somme des directions nouvelles dans lesquelles les médecins ont successivement engagé l’art de guérir pour arriver à une médecine contemporaine complexe [...] mais dont Celse ne dit ou ne laisse entendre nulle part qu'elle puisse être d'une qualité supérieure à la médecine des Anciens."

37. On the intertwinement between mythical and historical motifs in Celsus's reconstruction of the past of medicine see von Staden, Celsus as historian?, p. 253-54.

38. For the link between moral decadence and corruption and the progress of medical knowledge see Pr. 4-5 (pp. 17.18-18.2 Mrx = p. 14 Mudry = I, p. 3 Serbat): ...quos (scil. bonos mores) neque desidia neque luxuria vitiarunt; siquidem haec duo corpora prius in Graecia, deinde apud nos afflixerunt ideoque multiplex ista medicina, neque olim neque apud alias gentes necessaria, vix aliquos ex nobis ad senectutis principia perducit ("neither idleness nor luxuriousness had corrupted good habits, inasmuch as it is these two that have smitten and impaired human bodies, first in Greece, and then among us. And for that reason this complex medicine, neither necessary in former times nor necessary among other peoples, scarcely prolongs the lives of a few of us to the beginnings of old age"). See von Staden, Celsus as historian?, p. 259-64; F. Stok, "La medicina nell'enciclopedia latina," in ANRW II 37.1 (Berlin, New York: De Gruyter, 1993), pp. 393-444. pp. 427-439; E. Romano, "Il proemio di Celso fra sapere tecnico e cultura umanistica," in I. Mazzini, F. Fusco, ed., 
I testi di medicina latini antichi. Problemi filologici e storici, Atti del I. Convegno Internazionale, Macerata/San Severino M, 1984, Università di Macerata: Pubblicazioni della Facoltà di Lettere e Filosofia 28 (Roma: G. Bretschneider, 1985), pp. 131-140, pp. 138-40 and Medici e filosofi. Letteratura medica e società altoimperiale (Palermo: Il Grifo, 1991), pp. 19-28.

39. See De medicina, Pr. 2 (p. 17.6-8 Marx = p. 14 Mudry = I, p. 2 Serbat): ...quoniam adhuc rudem et vulgarem hanc scientiam Paulo subtilius exoluit, in deorum numerum receptus est (“... since he cultivated this science, hitherto crude and ordinary, in a slightly more refined way, he was counted among the gods"). As pointed out by von Staden, "Asclepius' progress divided what had been a universal medical tradition into minority and majority medical traditions: it separated Greece from the entire rest of the world. And, secondly, it segregated the lone human founder of a different medicine from humanity itself: Asclepius became deified [...] and paradoxically, once non-human, he became exceptionally able to benefit humanity through his improved, now divine, science" (Celsus as historian? p. 254).

40. von Staden, Celsus as historian?, p. 256.

41. For a detailed analysis of both Niccolo's Latin version and the Arab translation of On the Parts of the Medical Techne see von Staden, "Division, dissection, and specialisation: Galen's 'On the Parts of the Medical Techne,' in V. Nutton, ed., The Unknown Galen (London: University of London Institute of Classical Studies 2002), pp 19-45, pp. 21-23 (with bibliography).

42. Kühn substantially based his own judgment on the considerations put forward by Ackermann, whose Historia literaria Claudii Galeni was published by Kühn as the general introduction of his Claudii Galeni Opera Omnia; Ackermann, in his turn, had followed a sixteenth-century Juntine edition of Galen's works, which included it among the spurious works. After Kühn, only L. Choulant, C. Daremberg and J. Ilberg mentioned the treatise, and only briefly (for bibliography see von Staden, "Division, dissection, and specialisation," p. 20, n. 7).

43. Other Renaissance editions of Galen's works (antecedent or contemporary to the publication of Vesalius's De humani corporis fabrica) in which On the Parts of the Medical Techne is included are the edition by Rusticus Placentinus (Pavia, 1515-16), the Juntine editions of 1528, 1541-42 (the same edition to which Vesalius contributed by revising some translations, like that of the De anatomicis administrationibus by Guinther), 1550, the edition by Froben and Episcopius (Basel, respectively 1541 and 1549) and the edition by Gesner (Lyons, 1549-51). On this point see Durling, A chronological census. 
44. Theoretical attempts made to divide medicine into parts are characteristic of Greek thought (not only of the medical discourse), as shown by H. von Staden, Herophilus: the art of medicine in early Alexandria (Cambridge: Cambridge University Press, 1989), pp. 89-108.

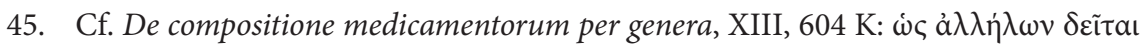

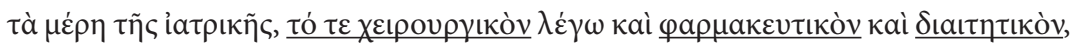

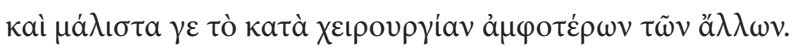

46. PAM, ch. 2 (p. 25.48 Schöne: "De partibus artis medicativae : eine verschollene griechische Schrift in Übersetzung des 14. Jahrhunderts", herausgegeben von H. Schöne, Greifswald: Julius Abel, 1911): “Quin etiam, si quidem omnia talia nominaverit aliquis partes medicative, qualia in Roma maxime et ad multa et minora dividere ea non cessant, dentales quosdam et auriculares et anales medicos nominantes, in aporiam veniet sermo maiorem, quamvis et his occasionem aliquam circa hoc prebuerit nomen optalmicorum, id est oculicorum, non nuper impositum, sed multo iam elapso tempore; si enim oculorum solorum fuerit aliquis medicus, non irrationabiliter videbitur et dentium aliquis alius esse et aliarum uniuscuiusque corporis partium proprius, ut sint tot medici quot particule, ac etiam apunctores et erniarum incisores alii quidam et lapidum incisores".

47. Von Staden, Division, dissection, and specialisation, pp. 40-45.

48. PAM, ch. 2 (p. 25.62 Schöne): "In parva enim civitate appungens aliquis oculos aut incidens ernias nequaquam nutrietur; Roma vero et Alexandria propter multitudinem hominum sufficientes sunt nutrire et eum, qui quamcumque artem operatur". It is noteworthy that also in modern times urbanisation was no doubt one the key social developments behind the specialization of medicine (see G. Rosen, The specialization of medicine with particular reference to Ophtalmology (New York: Froben Press, 1944).

49. In ch. 1-2 of the treatise (p. 23.11-25.68 Schöne), Galen makes a sort of list of all the possible (and often confuse) partitions of medicine that have been attempted by the physicians antecedent or contemporary to him. This list includes the following "partes": "curative" (also called "sanative"), "precustoditiva," "resumptiva," "euectica," "cirocomicam," "pedotroficam," "commotica," "vocitativa," "phisiologicam," "passiologicam," "materialem," "significativam," "causiologicam."

50. See von Staden, Division, dissection, and specialisation, pp. 29-40.

51. (ch. 8.3, p. 36.309 Schöne).

52. $P A M$, ch. 3 (p. 26.79 Schöne): "Sicut ergo corporis nostri particulas in anothomiis usque ad minimas secundum speciem, quas et elementa sensibilia vocamus, co- 
namur discere, ita oportet et artis minimas particulas. [Et elementa sensibilia] organa quidem ut caput, manus, pedes et huiusmodi, horum autem ipsorum rursus uniuscuiusque sunt partes, velut capitis quidem aures et facies et nasus et collum, ipsius vero nominati proprie capitis partes et cerebrum et ambe miringe et craneum et arterie et vene et membrane et nervi et corium, que omnes secundum primam incisionem inveniuntur."

53. See von Staden, Division, dissection, and specialisation, p. 29.

54. In On the parts of the medical techne an example of a "perceptible element" is provided by the fibres that constitute the two tunics or coats of the arteries. See Gal. De elementis 1.1-7, 6.28-29, 8.11 (CMG V 1,2, pp. 56, 110, 126); De naturalibus facultatibus 1.6, 3.15 (Scr. Min. III, pp. 109.18-19, 1109-15, 255.19-20); De sanitate tuenda 6.9.2. (CMG V 4,2, p. 184.20-26); In Hippocratis De articulis comm. 3.81 (XVIIIA 597.3-7 K).

55. PAM, ch. 4 (p. 27.114 Schöne): "Secundum igitur similitudinem exempli apunctivam quidem suffusionis artem talem partem totius medicative oportet putare esse, qualis est corporis particula quam appellamus organum; singula autem eius particularum proportionalis est sensibilibus corporis elementis.”.

56. von Staden, Division, dissection, and specialisation, p. 30.

57. A process of "epistemologization" of anatomy is that experienced by nineteenthcentury medicine at the rise of the anatomoclinical paradigm, which saw the light of day in Paris Faculty of Medicine. See P. Pinell, "Champ médical et processus de spécialisation," in La spécialisation de la médecine XIX-XXe siècle, Actes de la recherche en sciences sociales 156-157 (2005), p. 4-36: "La médecine anatomoclinique va rapidement imposer dans toute la médecine occidentale sa redéfinition de la maladie comme le fondement de la démarche clinique. Cette redéfinition accorde une importance centrale aux lésions tissulaires observées à l'autopsie: c'est à partir d'elles et non plus de leurs configurations symptomatiques que sont caractérisées les différentes entités pathologiques (dès lors qu’elle est caractérisée par la nature de ses lésions tissulaires, une maladie peut se présenter sous des configurations symptomatiques différentes quon appellera des 'formes cliniques')" (p. 8, n. 9). See also M. Foucault, Naissance de la clinique. Une archéologie du regard médical (Paris: Presses Universitaires de France, 1963; 5édition, 1997), pp. 127-149.

58. All the argumentative structure of the Ars Medica is triadic: it is founded upon the individuation of the three dispositions of the body (healthy, diseased, and neither healthy nor diseased), each of those is predicable in three different ways (as body, as cause, as sign). See V. Boudon, "Les définitions tripartites de la médecine chez 
Galien," in Aufstieg und Niedergang der römischen Welt II: 37.2 (Berlin: De Gruyter, 1994), pp. 1468-1490.

59. D. Laurenza, La ricerca dell'armonia. Rappresentazioni anatomiche nel Rinascimento (Firenze: Olschki, 2003), p. v: "autori come Leonardo, Berengario, Estienne, Cardano, Eustachio attribuiscono grande peso ad una rappresentazione anatomica compositiva o armonica, Vesalio definisce invece un modello rappresentativo prevalentemente analitico o dissettivo. Per intenderci: è sintetica o compositiva una immagine come quella leonardesca di un corpo femminile nella quale sono contemporaneamente rappresentati più apparati anatomici [...] Al contrario, in Vesalio l'ordine della dissezione e della rappresentazione coincidono: le tavole del De humani corporis fabrica mostrano le varie componenti anatomiche così come esse si presentano nel corso della dissezione."

60. Things are in fact far more complex and subtle, as the same Laurenza seems to admit few pages below (p. viii): "Il rapporto conflittuale tra rappresentazioni compositive e dissettive non contrappone solo questi autori tra loro, ma è anche presente all'interno delle loro opere [...] Così se Leonardo attribuisce il primato dimostrativo alle immagini compositive, realizza poi molti disegni analitici o dissettivi, anche se li vive in modo conflittuale in rapporto al dominante paradigma compositivo. Viceversa Vesalio pur prediligendo rappresentazioni analitico-dissettorie non può non confrontarsi con il modello armonico e sintetico".

61. It is worth remembering that resolutio and compositio were the two poles of the scientific method both in Scholastic and Renaissance culture (see Laurenza, p. ix).

62. Vesalius, Résumé (Vons-Velut 2008, p. 10) (English transl. is mine): “Caeterum hic nostram in Anatome totius medicae artis basi ac fundamento perdiscenda oscitantiam, et quam nobis qui medicinae nomen dedimus, pernecessaria sit humanarum partium notitia, haud demonstrandum assumpsi. [...] in morbis curandis eorum cognitionem primas, secundas ac tertias partes merito sibi vendicare."

63. G. Canguilhem, Études d'histoire et de philosophie des sciences (Paris: Vrin, 1968), pp. 27-35, p. 31. In the introduction to Les Belles Lettres edition of Vesalius's Epitome Jacqueline Vons and Stéphane Velut have remarked that Vesalius tried to combine the double imperative of an analytical observation and a synthetical description in the structure of the Epitome, "qui réunissait l'ordre de la dissection (ou le geste anatomique) et l'historia, la fabrica du corps (ou la description) tout en les séparant visuellement. Dès la page de titre, l'épître au lecteur annonce la division du livre en deux parties distinctes: une première partie est consacrée à une description très succincte de tout le corps, l'autre est constituée de gravures accom- 
pagnées d'explications. Fragmenté par l'ordre de la dissection, le corps retrouvait néanmoins son unité dans l'interdépendance des parties décrites" (Introduction à André Vésale, Résumé de ses livres sur la fabrique du corps humain (Andreae Vesalii Bruxellensis suorum de humani corporis fabrica librorum epitome), texte et traduction par J. Vons, introduction, notes et commentaire par J. Vons et S. Velut (Paris: Editions Latomus, 2008), pp. 64-65.

64. See Siraisi, "Vesalius and the reading of Galen's teleology", pp. 4-7: "The arrangement of the Fabrica as a whole is not designed to follow the sequence of any of Galen's actual anatomical treatises [...] Rather, the Fabrica presents in one volume an overview of the entire subject matter encompassed in Galenic anatomy, following Galen's ideal prescription for the study of the subject via dissection.”

65. This is the list of the chief Pre-Vesalian anatomical writings: Hieronymo Manfredi, Anothomia (1490); Gabriele Zerbi, Anatomiae Corporis Humani et Singulorum Illius Membrorum Liber (1502); Alessandro Benedetti, Anatomice, sive Historia Corporis Humani (1502); Antonio Benivieni, De Abditis Nonnullis ac Mirandis Morborum et Sanationum Causis (1507); Alessandro Achillini, Annotationes Anatomicae (1520); Berengario da Carpi, Commentaria...super Anatomia Mundini (1521)/ Isagogae Breves (1522); Andrés de Laguna, Anatomica Methodus, seu De Sectione Humani Corporis Contemplatio (1535); Nicolò Massa, Liber Introductorius Anatomiae sive Dissectionis Corporis Humani (1536); Johannnes Guintherius, Anatomicarum Institutionum secundum Galeni...libros Quattuor (1536); Johannes Dryander, Anatomiae...pars prior...quae ad caput spectant (1537); Giovanni Battista Canano, Musculorum Humani Corporis Picturata Dissectio (1541?); Charles Estienne, De Dissectione Partium Corporis Humani Libri Tres (1545). For a historical survey of these and other anatomical works antecedent to Vesalius's Fabrica see Lind, Pre-Vesalian Anatomy, pp. 3-19.

66. On Vesalius's notion of 'fabrica' and its derivation from Cicero's De Natura Deorum see the illuminating remarks of Pigeaud, pp. xviii-xxvi (cf. above, n. 28).

67. The plausibility of this parallel between the Greek kataskeue and the Latin "fabrica", which has been suggested to me by V. Barras, seems confirmed by a passage of Galen's De optima nostri corporis constitutione, IV, $741 \mathrm{~K}$, where a definition of

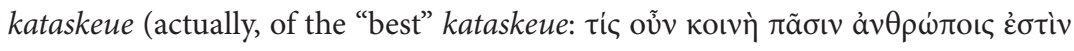

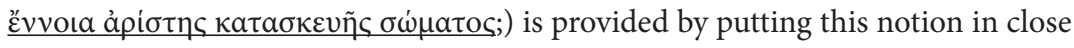
connection with the notions of "homoeomerous parts" and "instrumental organs", through which Galen indicates, respectively, the smallest perceptible constituents of the body (tissues, cartilages, bones, tendons, muscles, etc) and the "organs", or 


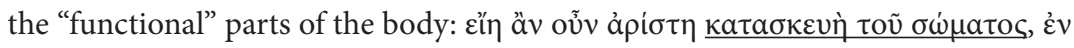

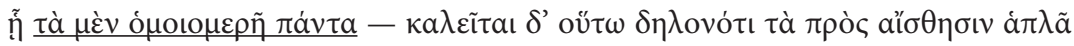

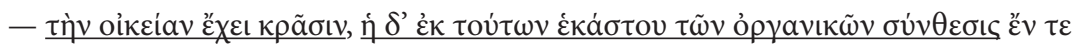

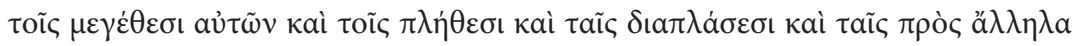

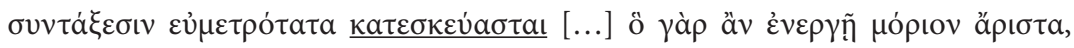

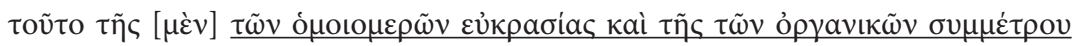

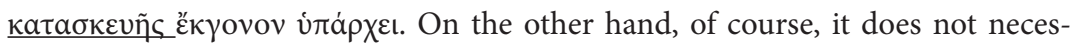
sarily imply a perfect correspondence between Galen's kataskeue and Vesalius's fabrica, as the former expresses an idea of "constitution" whose implications go far beyond anatomy including, for example, the nature and action of humours. On the other hand, the occurrences of kataskeue and kataskeuazein in extra-medical contexts suggest a close link between these notions and the ideas of "construction" and "fabrication", both from a material point of view (Hdt.1.186; Antipho 6.11; Pl.R.557d; Pl.Criti.113c) and from a logical and argumentative one (Arist. Rh.1401b3; Plu.2.1036b; Arist.EN1096a19; Arist. Metaph. 984b25).

68. The articulation of the skeleton from the various bones collected during dissections or in the cemeteries was essential to the teaching of anatomy and suggests that the 'unity of the body' attained by anatomy was a unity ex post, i.e. the result of a manipulation. M. Kornell ("Vesalius's method of articulating the skeleton and a drawing in the collection of the Wellcome Library", Medical History 44 [2000], pp. 97-110) has reconstructed Vesalius's method of articulating the skeleton very well. See, by way of example, how she describes the first steps of the construction of the skeleton (p. 102): "The construction of the skeleton began with the bones of the feet. The bones of the leg were next put together. In addition to wire, the tibia and femur were connected with a small rod that fixed the knee joint. The feet were then fixed to a rotatable wooden disk, which could be set in a box if desired. Once the legs were attached to the feet and the femurs inserted into the acetabula of the pelvis, one could then measure the height from the wooden disk to the sacrum and so judge the necessary length of the metal rod that was to be inserted in the sacrum, at a point enlarged with a knife, and threaded up the spine to hold the vertebrae in place and support the weight of the skeleton."

69. Vesalius, Fabrica, VI.16, 599 (transl. O'Malley, Andreas Vesalius of Brussels, p. 361). O'Malley (Andreas Vesalius of Brussels, pp. 112-113 and 119) has stressed the pedagogical aim of Vesalius's treatise.

70. See Vons-Velut, p. 59: “...Vésale, lui, regroupe les organes en ce que l’anatomie moderne nomme de grands appareils (digestif, locomoteur, nerveux, reproduc- 
teur) [...] Cette description annonce autant ce que sera la physiologie moderne que la chirurgie visant à restaurer la fonction."

71. See the list of medical specialties from L'Esculape (Paris: Société de médecins et des chirurgiens, vol. I, 1839): "Accouchemens [sic]; Maladies des femmes et des enfans [sic]; Orthopédie; Maladies des voies urinaires; Chirurgie dentaire; Maladies des yeux; Médecine légale; Maladies du système nerveux; Chirurgie herniaire; Maladies des oreilles; Hygiène et chirurgie militaire; Hygiène publique et privée; Maladies vénériennes; Maladies de la peau; Eaux minérales”. L'Esculape: Journal des spécialités médico-chirurgicales was published in Paris from 1839 to 1842 (the volume cited above is the first of the series) under the editorship of Dr. S. Furnari, a specialist in diseases of the eyes. On the contemporary forms of specialization of medical knowledge see G. Weisz, Divide and conquer: a comparative history of medical specialization (Oxford: Oxford University Press, 2006); P. Pinell, "Champ médical et processus de spécialisation," in La spécialisation de la médecine XIX-XX siècle, pp. 4-36; L. Premuda, "La naissance des spécialités," in Histoire de la pensée médicale en Occident, ed. M.D. Grmek (Paris: Seuil, 1999), t. 3, pp. 253-69.

72. See Weisz, p. xv: "During the earlier stage (to roughly 1890), specialization was organized primarily around the tasks of clinical research and training for general practitioners, it was largely a local phenomenon advanced by individuals or small groups. The major locus of competition during this period was the combination of medical school and teaching hospital". On the process of unification of medicine and surgery and the rise of specialties in the Paris Faculty of Medicine during the first half of nineteenth century see Weisz, pp. 3-25. 